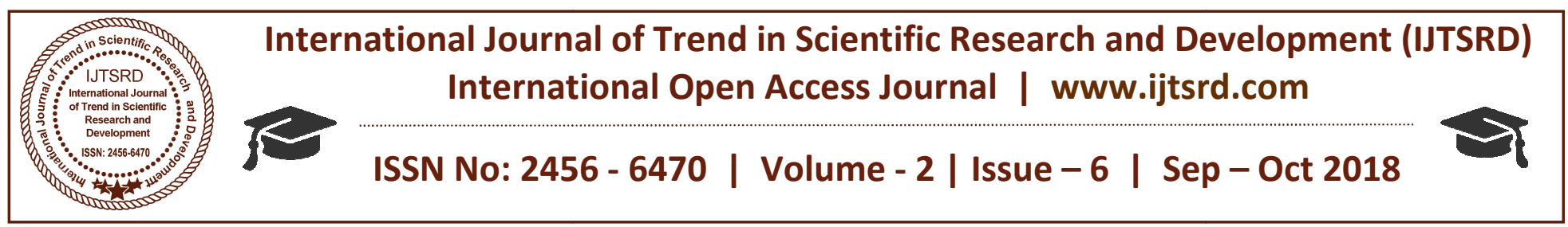

\title{
A Case Study of Physico-Chemical and Bacteriological Analysis of Ajnal River at Harda (M.P) During Monsoon Season
}

\author{
Anand Verma ${ }^{1}$, Sunil Kumar Bourasi ${ }^{2}$, Narendra Khore ${ }^{3}$ \\ Assistant Professor, ${ }^{1}$ Department of Microbiology, ${ }^{2}$ Department of Botany, ${ }^{3}$ Department of Chemistry, \\ Harda Degree College, Harda, Madhya Pradesh, India
}

\begin{abstract}
Water is a most valuable source for the survival of mankind. River Ajnal situated at Harda district (M.P.) it become a nalla during recent decades. The manmade activities such as discharge of waste materials in flowing water, religious used waste material is a main part of it. These activities affect the physico-chemical and bacteriological properties of river water and create the pollution of water and water-borne disease like Cholera, dysentery etc. collecting the sample from three different sites of river during monsoon season and analysed the physico-chemical parameter in Chemistry lab and identifying the isolated bacterial colonies which cultivated in nutrient media. TDS, Hardness, and DO was found in impermissible limit during research work and Colifoms, Faecal colifoms and Pseudomonas spp. were observed in water sample which causes the water borne illness. A brief attempt has been made to study the extent of change in quality of water in comparison to water quality standards of world health organisation (WHO).
\end{abstract}

Keyword: Survival, Ajnal river, physico-chemical, Cholera, Coliforms.

\section{INTRODUCTION}

Water the most important resource of nature is increasingly becoming a scare resource. Rivers are playing an important role as major water resource. Unfortunately, rivers are being polluted by indiscriminate disposal of sewage, religious used waste, statue immersion in river water, local community waste material, which affects the its physico-chemical properties and microbiological pollution of the water body (Koshy and Nayer 1999). On the emergence of floods during the monsoon season drain into river water which includes in municipal wastes and industrial waste it increases the bacteria population and change in physico-chemical parameters also. In the recent past, expanding human population, industrialisation, intensive agricultural practices and discharge of massive amount of waste water into the river have resulted in deterioration in water quality.

The water quality is fully depends on physicochemical and bacteriological parameters. physicochemical parameters such as $\mathrm{pH}$, temperature, light, dissolved solids, turbidity and biological agents like faecal Coliforms etc. are very important for determine the quality of river water.

Water is the source of diseses transmission. Feacal matter in water contains human enteric bacteria and therefore Faecal contamination is one of the most important criteria for water quality assessment (Scott et al.2003). Coliforms are the major microbial indicator of water quality monitoring. Therefore, bacteriological assessment, particularly for total Coliforms or Faecal colifroms is routinely carried out to ascertain the quality and portability of water. The determination of total Coliforms and total Faecal coliforms count is the widely used bacteriological methods for assessment of the quality of the drinking water. The presence of such bacteria can be taken as an inductor of Faecal contamination is present, how serious it is and what steps can be taken to eliminate is important.

The World Health Organisation (WHO, 1996) provides guidelines for drinking water for quality and recommended that no Faecal coliforms should be found in drinking water. Presence of faecal coliforms as E. coli serves as an indicator for the possible 
presence of other disease causing pathogens. Faecal colifrorms are selected members of the colifrom group of bacteria which are able to ferment lactose at $37{ }^{\circ} \mathrm{C}$ and fairly specific for the faeces of warm blooded animals. The bacteriological examination of water has a special significance in pollution studies, as it is a direct measurement of deleterious effect of pollution on human health. The present study focuses on the culturable bacterial diversity of the Ajnal River system for its pollution status.

\section{Materials and Methods \\ Study area}

Town Harda is a district place of M.P. situated at the south west region of the Madhya Pradesh its geological coordinate are $22.198^{\circ} \mathrm{N}, 77.1025^{\circ} \mathrm{E}$ town manned in the bank of Ajnal River. The physicochemical and Bacteriological study of three water sample were collected from different sites of river Ajnal during monsoon season from July 2018 to September 2018.

\section{Physico-chemical analysis}

The River water sample was collected in a clean plastic bottle of 2 litter capacity for physico-chemical and bacteriological study of water. Physico-chemical parameters such as water temperature $\mathrm{pH}$, electrical conductivity (EC), total dissolved solids (TDS), total hardness $(\mathrm{TH})$, chloride $(\mathrm{Cl})$, and dissolve oxygen (DO). All the physico-chemical parameters were analysed following the standard protocol of APHA (1998) [4].

\section{Bacteriological analysis}

Bacteriological analysis is designed to indicate the degree of pollution of water with sewage water, domestic waste water, and socio-culture activates contamination. The bacterial population in different samples were estimated by the pour plating method on different media using $1 \mathrm{ml}$ of suitable dilutions. All media plates were incubated at $37{ }^{\circ} \mathrm{C}$ for $24-48$ hours and final counts of colonies were noted. The water quality was determined by the standard Most Probable Number (MPN) method. Fermentation tubes were inoculated with 10,01 and $0.1 \mathrm{ml}$ aliquots of water sample (APHA 1998) the tubes incubated at 37 ${ }^{\circ} \mathrm{C}$ for 24 hour. Positive tubes producing acid and gas were used in estimating the presumptive MPN /100 $\mathrm{ml}$. Confirmed test was carried out by transferring a loopful of broth from a positive tube in to Brilliant green lactose bile (BGLB) broth, followed by incubation at $37^{\circ} \mathrm{C}$ for $24-48$ hours. The tubes were observed for gas formation. Completed test was performed by plating a loopful of broth from a positive (BGLB) tube on to an Eosin Methyline Blue (EMB) agar plate the plate were incubated at $37^{\circ} \mathrm{C}$ for 24- 48 hours and observed for dark red colony with metallic green sheen. Final Faecal coliform or E. coli counts as MPN/100 ml was calculated based on the completed test.

\section{Results and Discussion:}

The result are described in table A and table B

Table A: Showing Physico-chemical parameters of river Ajnal (Harda).

\begin{tabular}{|c|c|c|c|c|c|}
\hline S.No. & Parameters & WHO Standard, 1984 & Site I & Site II & Site III \\
\hline 1 & Temperature $\left({ }^{\circ} \mathrm{C}\right)$ & - & 24.6 & 23.8 & 27.5 \\
\hline 2 & $\mathrm{pH}$ & $7.0-8.5$ & 7.2 & 7.4 & 7.6 \\
\hline 3 & Conductivity $(\mu \mathrm{s} / \mathrm{cm})$ & 0.3 & 238 & 265 & 332 \\
\hline 4 & TDS $(\mathrm{mg} / \mathrm{lit})$ & 500 & 316 & 488 & 560 \\
\hline 5 & Total hardness & 100 & 212 & 198 & 256 \\
\hline 6 & Chloride $(\mathrm{mg} / \mathrm{lit})$ & 200 & 28.4 & 26.47 & 24.57 \\
\hline 7 & Dissolve Oxygen $(\mathrm{mg} / \mathrm{lit})$ & 5 & 4.17 & 4.96 & 5.45 \\
\hline
\end{tabular}

Table A: Showing Bacteriological parameters of river Ajnal (Harda).

\begin{tabular}{|c|c|c|c|c|c|}
\hline S. No. & Parameters & WHO Standard 1984 & Site I & Site II & Site III \\
\hline 1 & TC $\left(\times 10^{3}\right)$ & Nil & 48 & 42 & 37 \\
\hline 2 & TFC $($ MPN $/ 100 \mathrm{ml})$ & Nil & 1400 & 1600 & 958 \\
\hline 3 & Pseudomonas spp. $\left(\times 10^{3}\right)$ & Nil & 17 & 14 & 18 \\
\hline
\end{tabular}

Water Temperature: Temperature is one of the most important parameter of water because it affects the biotic as well as abiotic components of the ecosystem.
During Monsoon season water temperature varied from 23.8 to $27.5{ }^{\circ} \mathrm{C}$. The river water temperature 
usually depends on the season, geographic location, sampling time [5], [6].

pH: Potential of hydrogen ions is a measure of the concentration of hydrogen ions of water. This measurement indicates the acidity or alkalinity of the water. $\mathrm{pH}$ is one of the important factors that serve as an indicator of pollution of water body. Highest $\mathrm{pH}$ value of the sample was recorded as 7.6 at Bada pull near bypass (site III) and that of minimum 7.2 at Chakrighat (site I). The difference in the $\mathrm{pH}$ value of the sample might be due to fact that the accumulation of domestic sewage.

Electrical conductivity: Electrical conductivity (EC) ranged from $238-332 \mathrm{micros} / \mathrm{cm}$ at different sampling sites of river Ajnal .Usually higher EC value 332 at Bada pull (site III) indicate the presence of higher continent of dissolved salts in river water [7], [8], [9].

Total dissolve solids: The term TDS describes all solids (usually mineral salts) that are dissolved in water. TDS of the water sample varied from 316-560. Variation of dissolved solids in water could affect conductivity measurement. There is a relationship between conductivity and total dissolved in water. As more dissolved solids are added, water conductivity increases [10].

Total hardness: Calcium ions are important components of plant tissues and participate in various cellular functions. During monsoon season calcium varied from 198-256 mg/l. The lowest calcium hardness 198 was observed at site II while maximum $256 \mathrm{mg} /$ lit at site III.

Chloride: Chloride concentration is one of the most important indicators of water pollution [11]. It is one of the major anions found in water and are generally combined with calcium, magnesium or sodium. During the study period chloride value ranged from 24.57-28.40 mg/l. Maximum value of chloride at site I.

DO (Dissolve Oxygen): The dissolved oxygen concentration of river Ajnal varied from maximum $5.45 \mathrm{mg} / \mathrm{l}$ at site III and minimum of $4.17 \mathrm{mg} / \mathrm{l}$ at site I The change in dissolved oxygen content was mainly due to the solubility of dissolved oxygen increase with decreased in water temperature. The change in the content was mainly due to the utilization of these molecule by the aerobic bacteria present in the sample and release free $\mathrm{CO}_{2}$ as a result of decomposition. This was accordance to the findings of Moss [12], [13].

\section{Bacteriological analysis:}

Population of aquatic microbiota (bacterial spp.) are inflected by many environmental parameters. High level of pollution indicator bacteria in river water is also a common problem in urban and rural areas that often leads to out breaks of serious water born disease like Cholera, Dysentery etc. the bacteriological analysis revealed that the entire sample collected from three different sites of river Ajnal was contaminated with Coliform, Fecal coliform and Pseudomonas spp. and other and other pathogenic bacteria.

Microbial analysis is presented in table B. All three samples were found to have total coliform, total facal coliform and other pathogenic bacteria. The total Coliform and Facel coliform was higher in the monsoon season. In the Ajnal river total Facel coliform was in the range of $37-48\left(\times 10^{3}\right)$ and TFC was in the range of 958 to $1600(\mathrm{MPN}) / 100 \mathrm{ml}$.

The maximum range of TFC $1600 \mathrm{MPN} / 100 \mathrm{ml}$ was reported at site II and minimum range of TFC 958 was reported at site III

\section{Conclusions}

The present study reveals that the water quality of Ajnal river is deteriorated it was due to directly mixing of the domestic sewage, socio-cultural activities and other effluents in Ajnal river. Overall physico-chemical and bacteriological analysis Ajnal river water revealed that the river water was polluted by sewage, faecal contaminations and domestic waste and the water of the Ajnal river is not suitable for drinking and recreational purposes. To improve the quality of water, sewage treatment plant is essential. Therefore the discharged of effluents before treatment and other waste into Ajnal River should be controlled and enforced.

\section{Acknowledgement}

The author is thankful to Mr Girish Sinhal and Mrs Abhilasha Sinhal Directors of Harda Degree College, Harda for providing necessary laboratory facility and thankful to Dr. R. K. Patil Principal Harda Degree College, Harda for giving necessary support for research work 


\section{References:}

1. Koshy, M and Nayar, T. B. (2000). Water quality of river Pamba at Kozhencherry, pollution research, 19(4): 665-668. 2.

2. Mc Neely, R. N., Neimanis, V. P. and Dweyer L. 1979. Water quality source book: A guid to water quality parameters. Inland waters Directorate, Water Quality Branch Ottawa, Canada, pp:88

3. Munawar, M. (1970). A limnological studt of fresh water ponds of Hyderabad, India 1- The biotope. Hydrobiologia, 35: 127-162.

4. Apha (1998) standard methods for the examination of water and waste water, $20^{\text {th }}$ addition. USA, Washington DC.

5. Bibhas Rajkumar, Sharma G D (2013) seasonal bacteriological analysis of Barak river, Assam India. Applied water science 3:625-630.

6. Kumar Pawan and Shrivastava Pradeep (2015). Analysis of water qual;ity of river Narmada, international Journal of current research Vol. $7 \mathrm{pp}$. 24073-24076.

7. Bourasi S. K., Singh S D, Patil Pramod, Pwan Rathour (2018). Astudy of effect of physico- chemical parameter on Biodiversity of diatoms special refrance to Navicula in river Narmada AT Harda, M.P. India, international journal of life sciences6(2):575-578.

8. Reemela Maneesha, Geetha Saramanda Byragi Reddy (2017). Physic-chemical analysis of bore water samples in Chintapalli Mandal, Vishakhapatnam District, A.P., India. International journal of advanced science and research.vol 2; pp 23-25.

9. Anjana Sharma, Chandan R Bora and varsha shukla (2013). Evolution of seasonal changes in physic-chemical and bacteriological characteristics of water from the Narmada river (india) using multivariate analysis Natural resources search.

10. Abdullah, M. H and Musta, B.1999.Phreatic water quality of the turtle island of west Malaysia: Pulau Selingan and Pulau Bakungan Kechil. Boreneo Science, 6:1-9.

11. Ahipathy, M V and Puttaiah, E T. 2006. Ecological characteristics of Vrishabhavathy river in Bangalore (India). Environmantai Geology., 49: 1217-1222. 